\title{
COMMUNICATIONS
}

\section{FAKTOR - FAKTOR PERTENGKARAN ANTARA SUAMI DAN ISTRI DI DALAM RUMAH TANGGA SERTA PEMICUNYA \\ $1^{*}$ Christine Purnamasari Andu \\ ${ }^{1}$ Universitas Teknologi Sulawesi \\ * christine.andu@yahoo.com}

\section{ARTICLE INFO}

Received on 20 Desember 2020

Received in revised from 6 January 2021

Accepted 31 January 2021

Published on 31 January 2021

Keywords: (3-5 words)

Quarrel Factors,

Household

Husband dan Wife.

How to cite this article: Andu, Christine Purnamasari. (2021). Faktor-Faktor Pertengkaran Antara Suami dan Istri Di Dalam Rumah Tangga Serta Pemicunya.

Communications 3(1)18-42

\section{ABSTRACT}

The aims of this study is to know are the quarrel factors between husband and wife in a household and the caused of its quarrel. Primary data taken from the informants itself, and secondary data are collected from books, journals, websites, and other valid source to support this study completion. Informants consist of ten wives, and ten husbands, while some of those twenty were already widow and widower. Researcher used Expectancy Violations and Behaviorism Theory. Study showed that the quarrel factors between husband and wife from the husband point of viewed were: housedhold tasks and bad habbits $(42 \%)$, phone/social media and economy $(33 \%)$, and in-laws/other family $(25 \%)$. From the wife side were: disloyalty $(42 \%)$, economy and in-laws/other family
(33\%), household tasks, bad habits and commitment (25\%)

\section{ABSTRAK}

Tujuan penelitian ini adalah untuk mengetahui faktor - faktor pertengkaran antara suami dan istri di dalam rumah tangga dan pemicu pertengkaran tersebut. Data primer diambil dari para informan itu sendiri, dan data sekunder diambil dari buku, jurnal, website, dan sumber valid lainnya untuk mendukung penyelesaian penelitian ini. Informan terdiri dari sepuluh orang suami dan sepuluh orang istri, dimana beberapa dari informan tersebut ada yang telah menjadi janda dan duda. Peneliti menggunakan Teori Pelanggaran Harapan dan Teori Behaviorisme. Hasil penelitian menunjukkan bahwa faktor - faktor pertengkaran antara suami dan istri dari sudut pandang suami yaitu: pekerjaan rumah tangga dan kebiasaan buruk $(42 \%)$, ponsel/media sosial dan ekonomi (33\%),dan mertua/keluarga lain $(25 \%)$. Dari sudut pandang istri yaitu: ketidaksetiaan (42\%), ekonomi dan mertua/keluargalainya (33\%), pekerjaan rumah tangga, kebiasaan buruk dan komitmen $(25 \%)$. 


\section{PENDAHULUAN}

Setiap pria yang sudah menikah akan disebut sebagai suami, dan wanita sebagai istri. Pada umumnya suami diidentikan sebagai sosok yang wajib dalam menghidupi dan menafkahi keluarga serta wanita yang selalu diidentikan sebagai sosok yang mengurus rumah tangga termasuk didalamnya mengurus anak, suami, dan pekerjaan - pekerjaan rumah tangga lainnya, misalnya memasak, menyapu, menyetrika, dan lain sebagainya, meskipun seiring dengan perkembangan zaman tugas - tugas serta tanggung jawab patriarkis tersebut mulai mengalami perubahan serta kompromistis. Baik suami maupun istri keduanya bias menjadi sosok yang sama - sama mengelolah pekerjaan rumahtangga, maupun sebagai pekerja professional diluar rumah, namun tidak jarang pula seorang istri yang mengambil peran untuk bekerja menghidupi keluarga dan suami berada dirumah.

Pria dan wanita pada dasarnya adalah dua sosok yang sangat berbeda, baik dari segi kognitif, afektif, dan psikomotorik. Selain itu, perbedaan lainnya yang juga berkontribusi membentuk sikap dan karakter seorang pria dan wanita misalnya pola asuh, pendidikan, budaya, lingkungan, penghayatan terhadap agama maupun kepercayaan serta faktor - faktor lainnya. Pertengkaran dan perselisihan di dalam rumah tangga adalah hal yang wajar, namun jika konflik tersebut tidak disikapi dengan pemikiran yang baik serta didukung dengan cara komunikasi yang baik pula maka konflik akan berkepanjangan dan bias saja berujung pada perceraian.

\section{TINJAUAN PUSTAKA}

Brizendine (2010), dalam lqbal dan Fawzea (2020 : 8) mengatakan bahwa kita berharap bahwa lawan jenis bersikap seperti diri kita sendiri, kita menginginkannya untuk mencapai apa yang kita inginkan dan merasakan apa yang kita rasakan. Selain itu, ditambahkan pula oleh Brizendine (2010), dalam Iqbal dan Fawzea (2020 : 30) bahwa bagi laki - laki tindakan dianggap lebih bernilai daripada lewat ucapan saja. Namun disinilah hal yang sulit dipahami oleh perempuan. Perempuan menginginkan pernyataan jelas yang diucapkan laki - laki, karena hal tersebut akan membuat perempuan lebih tenang dan percaya diri. Karena laki laki lebih senang melakukan tindakan nyata, sedangkan perempuan lebih suka mendengar 
kata - kata, maka timbulah kesalahpahaman diantara keduanya. Dalam perspektif neuropsikologi, konflik dan perbedaan dalam rumah tangga wajar terjadi karena memang secara struktur, otak antara suami dan istri memang berbeda sehingga cara pandang serta cara menyelesaikan masalahpun juga berbeda.

Menurut Syuhud (2014 : 76), mengatakan bahwa salah satu kunci keharmonisan rumah tangga dan cara jitu menghindari konflik adalah kedua belah pihak harus melakukan kompromi. Menurut kamus Merriam Webster kompromi memiliki beberapa makna yaitu: (1) Penyelesaian perbedaan dengan cara arbitrasi ataukonsesi Bersama, (2) Dua pihak saling menyesuaikan diri dengan cara saling mengalah, (3) Mencapai kesepakatan dengan cara saling mengalah.

Setiap manusia tidak lepas dari hal yang bernama ego, seperti merasa lebih baik dari orang lain, lebih pintar, lebih mampu, lebih benar, dan hal - hal lainnya yang cenderung mengagung - agungkan atau mengunggulkan diri sendiri. Orang yang memiliki ego dominan cenderung sulit untuk berbesar hati menerima kritik dari orang lain. Pasangan dengan ego dominan seperti ini cenderung akan berlaku defensif jika mendapatkan kritik dari pasangannya, karena merasa bahwa tidak ada hal keliru yang ia lakukan atau merasa selalu benar. Sikap ego diantara suami dan istri harus diredam atau di minimalisir, karena jika sifat ini terus menerus dibiarkan maka pasangan akan lebih sering bertengkar dari pada berdamai.

Menurut buku yang ditulis oleh Hadiwardoyo, Surat Untuk Suami Istri Katolik mengemukan bahwa setiap keluarga pasti pernah atau sedang menghadapi masalah. Masalah yang dihadapi sangat beranekaragam, baik dari segi bobot maupun jenisnya. Ada yang berat sehingga sangat sulit untuk diatasi, dan adapula yang begitu ringan sehingga tidak terasa sebagai suatu masalah, Hadiwardoyo (2002: 21). Ditambahkan pula oleh Hadiwardoyo bahwa masalah yang muncul bisa karena faktor:

1. Ekonomi seperti utang, pengangguran, kemalasan, pemborosan, ketidakadilan, pemerasan, penipuan, cacat, atau penyakit, sehingga mengakibatkan rasa minder, malu, godaan untuk melakukan korupsi atau bahkan keputusasaan.

2. Relasi yang sulit diantara suami dan istri seperti ketidakdewasaan, ketidakcocokan, atau berbagai perbedaan yang sulit didamaikan, sehingga mengakibatkan percekcokan, saling menyalahkan, dan berbagai sikap emosional yang kurang terkendali. 
Menurut Gunawan dalam bukunya yang berjudul, Bagaimana Mengubah Suami/Istri Anda Menjadi Lebih Romantis, disebutkan bahwa, untuk membahagiakan orang lain, maka Anda harus bahagia terlebih dahulu, caranya adalah dengan mencintai diri sendiri. Agar suami/istri Anda bahagia, maka Anda harus bahagia terlebih dahulu. Saat Anda bahagia, vibrasi energi Anda akan menjadi lebih positif. Jika Anda bahagia, cara Anda berinteraksi dengan suami dan anak - anak Anda akan sangat berbeda dibandingkan jika Anda stress ataupun membenci diri sendiri, Gunawan (2020: 111).

Pertengkaran dalam rumah tangga antara suami dan istri memang tidak bias terhindarkan. Setiap rumah tangga pasti memiliki pergumulannya masing - masing. Kedua pihak baik suami dan istri, harus memiliki kendali pada diri masing - masing agar situasi yang tidak menyenangkan tersebut tidak semakin menjadi lebih parah, tapi bagaimana agar perlahan dapat dikendalikan. Seperti penjelasan sebelumnya yang dikutip dari berbagai sumber buku dijelaskan bahwa suami dan istri adalah dua jenis yang berbeda, sehingga dibutuhkan control diri yang baik dari kedua pihak tersebut agar mampu mengendalikan situasi konflik yang tengah dihadapi.

Sawitri Supdardi dalam Dinata (2018: 32) menyebutkan bahwa ada beberapa sumber konflik dalam perkawinan yang berpengaruh satu sama lain secara dinamis, yaitu adanya perbedaan yang tidak terelakkan, perbedaan harapan, kepekaan, keintiman dari perkawinan, aspek komulatif dalam perkawinan, persaingan dalam perkawinan, dan perubahan - perubahan dalam perkawinan. Ketika dua orang menyatu dalam perkawinan, sejatinya secara esensial mereka berbeda. Pengalaman, kebutuhan, dan nilai - nilai yang mereka anut pun berbeda beda, sehingga kondisi - kondisi inilah yang memberikan pengaruh pada sudut pandangnya dalam menghadapi permasalahan keluarga.

Dalam kehidupan ini, tidak ada bentuk pernikahan yang sempurna maupun ideal, karena sejatinya pernikahan merupakan komitmen sadar yang dibangun diantara dua orang yang mau berupaya untuk terus membenahi diri dan berkompromi satu sama lain agar pemicu pertengkaran dapat diminimalisir dengan baik. 


\section{METODOLOGI}

Pada penelitian ini metode yang digunakan adalah metode kualitatif interaktif dengan jumlah informan wanita sebanyak sepuluh orang dengan kisaran usia 25 tahun - 35 tahun dan pria (suami) sebanyak sepuluh orang dengan kisaran usia 25 tahun - 40 tahun, sehingga total jumlah informan adalah sebanyak dua puluh orang, dengan wilayah domisili di Kota Makassar.

\section{Gambar 1.1 Penelitian Kualitatif Menurut Creswell}

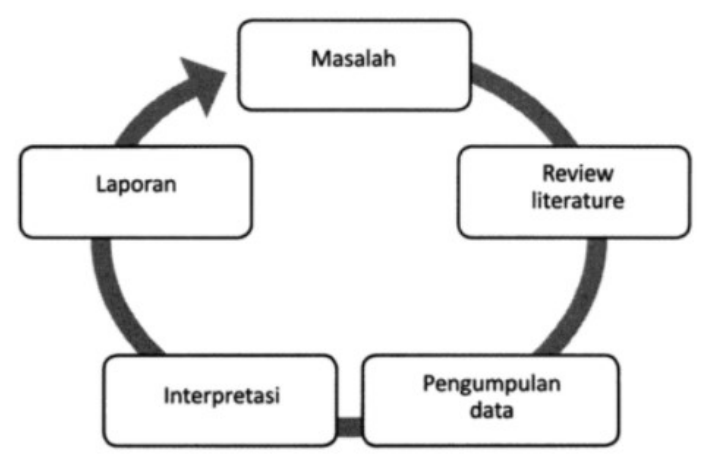

\section{Sumber :Buku, Semiawan (2010: 6)}

Menurut Creswell (2008), dalam Semiawan (2010: 7) menyebutkan bahwa penelitian kualitatif adalah suatu pendekatan atau penelusuran untuk mengeksplorasi dan memahami gejala sentral dengan cara mewawancarai peserta atau partisipan dengan mengajukan pertanyaan yang umum dan agak luas. Hasil akhir dari penelitian kualitatif dituangkan dalam bentuk laporan tertulis.

\section{Gambar 1.2 Penelitian Kualitatif Menurut Creswell}

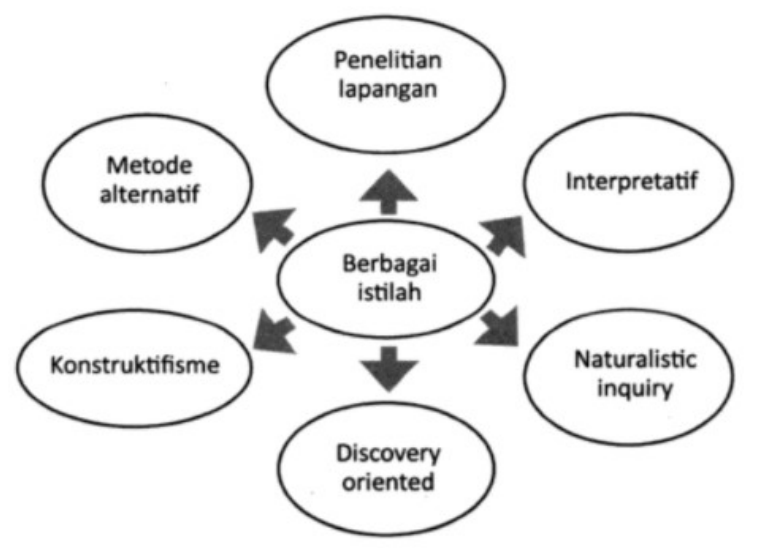

Sumber :Buku, Semiawan (2010 : 9) 
Penelitian kualitatif banyak terpengaruh oleh refleksi pribadi, pengetahuan, latar belakang sosial, kreatifitas, dan kemampuan personal peneliti. Penelitian kualitatif disebut juga pencarian alamiah (naturalistic inquiry) karena menekankan pentingnya pemahaman tentang situasi alamiah partisipan, lungkungan dan tempatnya, Semiawan (2010: 11).

Utarini (2020: 193) menyebutkan bahwa penelitian kualitatif adalah penelitian yang mengandalkan manusia sebagai instrument penelitiannya serta menggunakan metode wawancara yang bertujuan untuk mengeksplorasi pengalaman, perilaku, maupun pendapat, tanpa memberikan nasihat tertentu, dilakukan dengan penuh kaidah etika, serta didahului dengan persetujuan responden untuk diwawancarai.

Menurut Denzin \& Lincoln (1994), dalam Anggito \& Setiawan (2018: 7) menyebutkan bahwa penelitian kualitatif adalah penelitian yang menggunakan latar alamiah dengan maksud menafsirkan fenomena yang terjadi dan dilakukan dengan jalan melibatkan berbagai metode yang ada. Erikson (1968) menyatakan bahwa penelitian kualitatif berusaha untuk menemukan dan menggambarkan secara naratif kegiatan yang dilakukan dan dampak dari tindakan yang dilakukan dalam kehidupan mereka.

Penelitian kualitatif banyak digunakan dalam penelitian dibidang social serta merupakan penelitian yang hasil penelitiannya tidak diperoleh melalui prosedur statistik atau metode kuantifikasi yang lain. Penelitian kualitatif merupakan penelitian yang menekankan pada pemahaman mengenai masalah - masalah dalam kehidupan social berdasarkan kondisi realitas atau natural setting yang holistis, kompleks, dan rinci, Anggito \& Setiawan (2018: 9).

Pengumpulan informasi untuk menyelesaikan penelitian ini memakan waktu sekitar satu (1) bulan. Pada peneltian ini, sumber data yang digunakan adalah primer dan skunder. Data primer merupakan data utama atau hasil wawancara langsung dengan para informan, serta data sekunder yang merupakan data tambahan yang didapatkan baik melalui buku, jurnal, dokumen, serta sumber - sumber lainnya yang dapat mendukung penyelesaian penelitian ini.

Data primer adalah data asli yang dikumpulkan sendiri oleh priset. Proses pengumpulan data primer memakan waktu yang relatif lebih lama dan relatif lebih rumit dibandingkan dengan 
data sekunder. Data primer cenderung memiliki kredibilitas yang relatif tinggi karena periset mampu mengontrol data yang akan digunakan dalam risetnya, Istijanto (2009: 45).

\section{Gambar 1.3 llustrasi Data Primer}

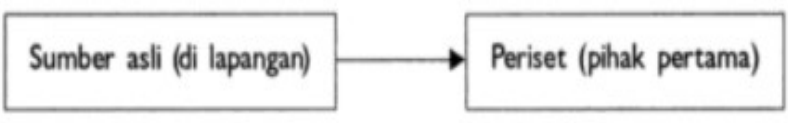

\section{Sumber :Buku, Istijanto (2009 : 45)}

Data sekunder adalah data yang telah dikumpulkan oleh pihak lain (bukan oleh periset sendiri) untuk tujuan yang lain. Ini menjelaskan bahwa, periset sekedar mencatat, mengakses, atau meminta data tersebut (kadang sudah berbentuk informasi) kepada pihak lain yang telah mengumpulkannya dilapangan, Istiajnto (2009: 38).

\section{Gambar 1.4llustrasi Data Sekunder}

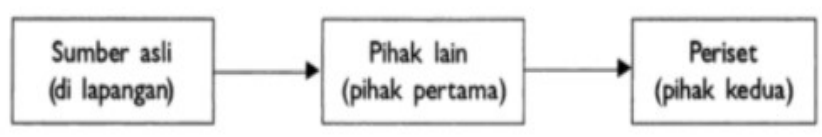

\section{Sumber: Buku, Istijanto (2009 : 39)}

Penelitian ini menggunakan teknik pengumpulan data berupa wawancara mendalam dengan para informan. Peneliti harus melakukan wawancara mendalam dengan para informan untuk mendapatkan informasi yang valid dan sesuai dengan fakta yang terjadi didalam rumah tangga mereka masing - masing.

Morissan, (2019: 83) menyebutkan bahwa wawancara mendalam sangat berguna bagi penelitian karena tujuannya adalah untuk mendapatkan informasi yang rinci mengenai pemikiran serta perilaku seseorang atau dengan kata lain wawancara mendalam digunakan untuk menjelajahi permasalahan baru.

Manzilati, (2017: 72) berpendapat bahwa wawancara mendalam merupakan interaksi atau pembicaraan yang terjadi antara seorang pewawancara dengan seorang informan. 


\section{HASIL PENELITIAN DAN PEMBAHASAN}

Menurut artikel tahun 2019 yang ditulis pada laman parenting.orami.co.id menyebutkan ada lima jenis pertengkaran yang biasanya terjadi di dalam rumah tangga. Pertama, Kurangnya intensitas berhubungan seks. Banyak faktor yang menyebabkan berkurangnya intensitas berhubungan seks suami istri seperti, factor anak - anak, stress, penyakit, dan kejadian kejadian dalam perjalanan kehidupan lainnya merubah keadaan.

Kedua, Pasangan lebih sering menghabiskan waktu dengan ponselnya. Pasangan yang terlalu sibuk dengan ponselnya cenderung akan lebih banyak menghabiskan waktu disitu dibandingkan dengan pasangan. Waktu berharga yang seharusnya bisa digunakan untuk membicarakan hal - hal yang ringan dan membangun keintiman terbuang sia - sia.

Ketiga, Tugas - tugas rumah tangga. Pertengkaran juga bisa terjadi karena ketidakadilan dalam pengerjaan tugas - tugas rumah tangga, dimana salah satu pasangan mengerjakan tugas - tugas rumah tangga lebih banyak dibandingan pasangan mereka. Hal ini sangat berkaitan dengan perasaan dimana lelah dan merasa tidak dihargai bercampur menjadi pemicu pertengkaran.

Keempat, Tidak cocok dengan kebiasaan pasangan. Ketidakcocokan kebiasaan bahkan untuk hal kecil sekalipun bias menjadi pemicu pertengkaran, misalnya saja, salah satu pihak menjadi yang paling rajin membuang sampah, dan pihak lainnya berlaku pasif, atau salah satu pihak adalah pribadi yang rajin membersihkan rumah, dimana pihak lainnya tidak memiliki semangat yang sama dalam hal kebersihan. Salah satu pihak akan merasa diabaikan, tidak dihargai, dan bekerja dengan susah payah seorang diri untuk mengatasi tugas - tugas rumah tangga, dimana pihak lainnya merasa aman karena pasangan mereka memiliki semangat yang besar dalam hal tersebut.

Kelima, merasa tidak lagi mengenal pasangan dengan baik. Seiring berjalannya waktu, banyak pasangan yang merasa tidak lagi mengenal satu sama lain, karena mereka memiliki tambahan kesibukan lainnya, seperti anak - anak, pekerjaan, dan hal - hal lainnya sehingga cenderung mengabaikan pasangan dan menganggap bahwa semuanya berjalan dengan baik. 
Selalu berdiskusi dan bertanya dengan pasangan adalah hal yang dapat menjaga kestabilan pasangan dalam berumah tangga.

Artikel lainnya yang juga membahas mengenai hal tersebut ditulis pada laman lifestyle.kompas.com yang menyebutkan setidaknya ada sepuluh hal yang menjadi penyebab pertengkaran antara suami istri. Pertama, Salah satu pasangan merasa memiliki komitmen hubugan yang lebih besar dibandingkan yang lainnya. Hal ini terjadi karena salah satu pasangan merasa memiliki effort yang lebih besar dalam membangun hubungan dibandingan dengan pasangannya.

Kedua, tugas - tugas rumah tangga. Ibu bekerja sekaligus sebagai ibu rumah tangga memiliki pekerjaan yang lebih banyak, terutama jika pasangan tidak memiliki empati untuk membantu menyelesaikan pekerjaan domestik rumah tangga tersebut. Hal ini bias menjadi pemicu pertengkaran, karena salah satu pihak merasa kelelahan menggunakan waktu dikantor kemudian harus tetap dengan kondisi prima bertemu dan berhadapan dengan tugas - tugas rumah tangga sepulang kerja.

Ketiga, Media sosial. Pasangan yang lebih banyak menghabiskan waktu untuk media sosial akan merugikan pasangan yang lainnya. Misalnya saja, suami yang sibuk dengan ponsel atau media sosialnya akan mengurangi jatahwaktu yang seharusnya bias digunakan secara berkualitas dengan pasangannya seperti merencanakan hal - hal demi masa depan keluarga, mengerjakan pekerjaan rumah tangga yang belum selesai, dan hal produktif lainnya yang menjadi tanggung jawab bersama.

Keempat Uang. Bukan rahasia lagi jika uang bisa menjadi pemicu pertengkaran dalam rumah tangga. Misalnya saja, salah satu pihak menghasilkan uang dan pihak lainnya tidak, atau salah satu pihak menghasilkan uang yang lebih banyak dibandingkan pihak lainnya, perasaan bersaing, merasa lebih superior, maupun minder dapat terjadi. Contoh lain, salah satu pihak merupakan saver dan pihak lainnya menjadi spender, dimana salah satu pihak menjadi yang paling ketat dalam menabung, dan pihak lainnya cenderung dengan mudah mengeluarkan uang atau boros. 
Kelima, Memprioritaskan pekerjaan lebih dibandingkan hubungan. Lebih memprioritaskan pekerjaan secara tidak proporsional dibandingkan hubungan akan menyebabkan hubungan tersebut menjadi dingin dan tidak intim karena kurangnya interaksi.

Keenam, Kecanduan. Pasangan yang memiliki ketergantungan dengan obat - obatan ataupun minuman keras juga menjadi pemicu pertengkaran dalam rumah tangga. Ketujuh, Pertengkaran setelah punya anak. Banyak pasangan baik suami maupun istri yang lebih mencurahkan waktu mereka untuk anak, sehingga salah satu pihak dari pasangan tersebut merasa terabaikan. Hal ini bisa menyebabkan kurangnya komunikasi sehingga dengan mudah memicu pertengkaran bahkan untuk hal - hal yang sederhana sekalipun.

Kedelapan, Hubungan intim.Keinginan untuk berhubungan intim yang tidak seimbang. Misalnya saja, suami selalu berinisiatif atau menginginkan hubungan intim, namun istri tidak memiliki keinginan sebesar suami bisa jadi karena faktor lelah, dan lain sebagainya.

Kesembilan, Ketidaksetiaan. Salah satu pasangan berlaku tidak setia terhadap pasangannya atau selingkuh. Kesepuluh, Pengasuhan anak. Dimana salah satu pihak lebih ketat terhadap anak dan pihak lainnya lebih toleran, misalnya saja apakah anak boleh menonton handphone sebelum usia 3 tahun atau tidak.

Dari kutipan artikel yang terdapat pada laman parenting.orami.co.id (2019) dan lifestyle.kompas.com (2020) mengenai faktor - faktor pertengkaran suami istri dalam rumah tangga, terdapat banyak kesamaan antara artikel tersebut dengan hasil wawancara dengan para informan. Menurut informan ada dua belas faktor-faktor umum penyebab pertengkaran suami dan istri, yaitu: (1) Seks, (2) Ponsel atau Media Sosial, (3) Pekerjaan Rumah Tangga, (4) Kebiasaan Buruk, (5) Komitmen, (6) Ekonomi, (7) Pekerjaan Prioritas, (8) Kecanduan, (9) Anak, (10) Ketidaksetiaan, (11) Pengasuhan Anak, (12) Mertua atau keluarga lainnya.

Dua belas hal di atas menjadi pokok pertengkaran antara suami dan istri yang dirangkum oleh peneliti berdasarkan hasil wawancara dengan para informan. Pokok - pokok tersebut kemudian akan dipetakan lagi oleh peneliti menjadi dua bagian yang ditinjau dari sudut pandang wanita (istri) dan sudut pandang pria (suami). Hal ini untuk memudahkan para pembaca melihat mengenai hal - hal apa saja yang pada umumnya menjadi sumber keributan 
didalam rumah tangga baik dari sisi istri maupun suami yang dimana pada bagian pendahuluan telah dijelaskan bahwa wanita dan pria memiliki banyak perbedaan termasuk dalam hal sudut pandang, dan lain sebagainya.

Tabel 1.1 Faktor - Faktor Umum Pertengkaran dari Sudut Pandang Istri

\begin{tabular}{|l|l|l|l|l|l|l|l|l|l|l|l|}
\hline No & Faktor-Faktor Umum Pertengkaran (Istri) & 1 & 2 & 3 & 4 & 5 & 6 & 7 & 8 & 9 & 10 \\
\hline 1 & Ponsel/Sosial Media & 1 & & & 1 & & & & & & \\
\hline 2 & Pekerjaan Rumah Tangga & 2 & & & & 1 & & 2 & 1 & & \\
\hline 3 & Pengasuhan Anak & 3 & & & & 2 & & & 3 & & \\
\hline 4 & Seks & & 1 & & & & & 1 & & & \\
\hline 5 & Komitmen & 2 & & & & 1 & & 2 & & 2 \\
\hline 6 & Ketidaksetiaan & 3 & 2 & & & 2 & & & 3 & \\
\hline 7 & Kecanduan & & & 1 & & & & & & & \\
\hline 8 & Mertua/ Keluarga lainnya & & & 3 & 3 & 3 & 3 & & & & \\
\hline 9 & Pekerjaan Prioritas Utama & & & & 2 & & & & & & \\
\hline 10 & Ekonomi & & & & & & & & & 1 & 1 \\
\hline 11 & Kebiasaan Buruk & & & & & & & 3 & & 2 & 3 \\
\hline
\end{tabular}

Menurut informan istri yang pertama ada 3 hal yang seringkali menjadi pemicu pertengkaran. Pertama adalah ponsel/Sosial Media. Suami informan pertama kerap kali lebih banyak menghabiskan waktu dengan bermain ponsel termasuk didalamnya sosial media, dibandingkan menggunakan waktunya untuk ngobrol atau diskusi dengannya. Kedua, adalah Pekerjaan Rumah Tangga. Informan merupakan ibu bekerja sekaligus ibu rumah tangga, oleh sebab itu ia berharap bahwa suaminya lebih peka untuk membantu menyelesaikan pekerjaan rumah tangga, karena menurut informan ia tidak hanya sebagai ibu rumah saja tapi juga ikut andil membantu suami un tuk memenuhi kebutuhan keluarga sehingga sudah sewajarnya jika pekerjaan rumah tangga dikerjakan secara bersama - sama, tidak membebankan sepenuhnya kepada istri. Ketiga adalah pengasuhan Anak. Informan menganggap suami kurang terlibat dalam hal pengasuhan anak, seperti mengajak bermain, membantu belajar, melatih kemandirian, dan lain sebagainya. 
Menurut informan istri yang kedua ada3 hal yang seringkali menjadi pemicu pertengkaran. Pertama adalah seks. Informan kedua memberi komentar bahwa suaminya memiliki libido seks yang tinggi. Hal yang menjadi pokok permasalahan adalah kondisi mereka yang long distance dimana sang suami merupakan seorang pelayar dan informan mensinyalir bahwa suaminya melakukan penghianatan. Kedua, komitmen. Suami informan jarang mengubungi informan, sehingga menjadi pemicu pertengkaran karena informan menganggap bahwa suaminya kurang memiliki komitmen terhadap pernikahan mereka dengan situasi long distance seperti itu. Ketiga adalah ketidaksetiaan. Informan memberikan informasi bahwa suaminya berlaku tidak setia dengan menghapus banyak percakapan dengan perempuan lain di ponselnya sebelum akan bertemu dengan informan. Sebelumnya informan pernah mendapati beberapa percakapan dengan perempuan lain di ponsel suaminya sebelum akhirnya semua dihapus oleh sang suami.

Menurut informan istri yang ketiga ada 3 hal yang seringkali menjadi pemicu pertengkaran. Pertama adalah kecanduan. Informan mengatakan bahwa suaminya adalah pecandu obat obatan terlarang sehingga kerap kali melakukan tindakan - tindakan kasar kepada informan. Hal ini menimbulkan perasaan tidak aman hingga dapat mengancam nyawa informan, yang mengakibatkan informan memilih jalan untuk memproses perceraian. Kedua, adalah ketidaksetiaan. Suami informan berlaku tidak setia dengan menghubungi perempuan lain pada malam hari dan dilakukan diluar rumah. Ketiga, adalah mertua/Keluarga Lainnya. Informan mengatakan bahwa mertua perempuannya seringkali bersikap tidak adil dan lebih mengutamakan anaknya. Kesalahan kecil yang dilakukan oleh informan akan dibesar besarkan oleh mertua perempuannya. Informan merasa tidak nyaman tinggal bersama mertua, namun sang suami pun tidak mampu mengupayakan hunian secara mandiri.

Menurut informan istri yang keempat ada 3 hal yang seringkali menjadi pemicu pertengkaran. Pertama, Ponsel/Sosial Media. Informan keempat mengatakan bahwa suaminya lebih sering berinteraksi dengan ponselnya dibandingkan ngobrol dengannya. Pada wawancara yang dilakukan dengan peneliti, informan mengatakan bahwa suaminya ketika sibuk dengan ponselnya cenderung menghindar saat didekati olehnya. la juga mengatakan bahwa mereka jarang membicarakan hal - hal dalam waktu yang lama, bahkan jarang makan secara bersama - sama. la merasa suaminya berada di dunia lain. Kedua, Pekerjaan Prioritas Utama. Informan menyebutkan bahwa, saat ia menanyakan pada suaminya mengapa selalu berinteraksi 
dengan ponsel, suaminya menjawab bahwa terkait urusan kantor. Ketiga, adalah mertua/Keluarga Lainnya. Saat sedang berkonflik dengan sang suami, informan mengatakan bahwa mertua perempuannya selalu berat sebelah dalam bersikap. Informan dan sang suami masih tinggal bersama dengan sang mertua atau orang tua pihak suami.

Menurut informan istri yang kelima ada 3 hal yang seringkali menjadi pemicu pertengkaran. Pertama adalah pekerjaan Rumah Tangga. Informan merupakan ibu bekerja sekaligus ibu rumah tangga. la sering berbagi pekerjaan dengan sang suami, dan kadangkala sang suami tidak terima jika informan meminta tolong untuk mengerjakan atau menyelesaikan satu atau dua pekerjaan rumah tangga yang tidak sempat dikerjakan oleh informan. Hal ini kerap menjadi bahan pertengkaran karena informan merasa bahwa mereka berdua sama - sama bekerja oleh sebab itu pekerjaan rumah tangga pun alangkah baiknya jika dikerjakan secara bersama - sama. Informan mengatakan bahwa sang suami sering mengadu pada orang tuanya jika mereka sedang dalam situasi konflik. la merasa suaminya tidak bijaksana dalam menyelesaikan masalah internal rumah tangganya. Kedua, Pengasuhan Anak. Sang suami kurang ingin membantu dalam pengasuhan anak secara bergantian yang baru berusia 6 bulan. Suaminya sering mengeluh jika harus menjaga anak mereka dalam waktu yang lama, misalnya saat informan sedang mandi atau mengerjakan sesuatu. Oleh sebab itu informan dibantu oleh ibu kandungnya. Ketiga, mertua/Keluarga Lainnya. Jika informan dan sang suami bertengkar, mertua selalu menyalahkan informan dengan melontarkan sindiran - sindiran yang tidak mengenakkan hati. Informan dan sang mertua tinggal secara terpisah, namun sang suami kerap pulang kerumah orang tuanya jika sedang berkonflik dengan informan.

Menurut informan istri yang keenam ada 3 hal yang seringkali menjadi pemicu pertengkaran. Pertama, komitmen. Sang mantan suami tidak memiliki komitmen dalam membangun rumah tangga. Perceraian yang dialami oleh informan keenam ini salah satu faktornya adalah kurangnya komiten sang mantan suami dalam memberikan nafkah kepada informan dan anaknya, padahal sang mantan suami memiliki pekerjaan yang cukup baik yaitu seorang pelaut. Informan memutuskan untuk mengakhiri pernikahan mereka karena kurangnya rasa tanggungjawab sebagai kepala keluarga. Kedua, Ketidaksetiaan. Informan mengatakan bahwa sang mantan suami adalah pribadi yang tidak setia pada keluarga. Ketiga, mertua/Keluarga Lainnya : Informan menginformasikan bahwa pernikahan mereka memang tidak direstui oleh pihak keluarga sang suami karena persoalan status sosial. 
Menurut informan istri yang ketujuh ada 3 hal yang seringkali menjadi pemicu pertengkaran. Pertama, seks. Informan merasa bahwa suaminya sangat tidak romantis dan setelah memiliki dua anak mereka jarang melakukan hubungan intim. Informan merasa sangat sedih dan kecewa dengan sikap sang suami tersebut namun tidak terbuka menceritakan alasan dibalik sikapnya tersebut. la mengatakan bahwa ia tidak mendapatkan kehangatan dalam rumah tangga sebagai seorang istri. Kedua, pekerjaan Rumah Tangga. Sang suami jarang membantu informan mengerjakan pekerjaan rumah tangga. Informan kadang merasa stress dengan tindakan dan sikap suaminya tersebut apalagi mereka memiliki dua orang anak yang masih kecil yang juga perlu mendapat perhatian dan pengasuhan. Ketiga, ekonomi. Informan juga harus mendapatkan tambahan penghasilan disamping pekerjaan tetap yang ia jalani sekarang. la pernah berada pada titik dimana sang suami tidak memiliki pekerjaan karena adanya pemutusan hubungan kerja (PHK), ditambah lagi sang suami yang menggunakan kartu kredit. Saat ini sang suami sudah memiliki pekerjaan lagi namun gaji yang diterima menurut informan hanya cukup dipakai untuk membayar gaji asisten rumah tangga, dan selebihnya harus ditanggung oleh informan.

Menurut informan istri yang kedelapan, ada 3 hal yang seringkali menjadi pemicu pertengkaran. Pertama, kebiasaan buruk. Sang mantan suami adalah tipikal orang yang menurut informan berperangai kasar. Sang mantan suami kerap menggunakan kekerasaan saat sedang dalam situasi konflik dengannya. Kedua, ekonomi. Sang suami tidak memberi nafkah pada informan padahal memiliki pekerjaan yang bagus. Informan mengatakan bahwa sang mantan suami memiliki kartu kredit yang penggunaanya bukan untuk kebutuhan rumah tangga sehingga seringkali menimbulkan pertengkaran karena sang mantan suami cenderung boros dan menggunakan uangnya tidak untuk hal - hal yang prioritas. Ketiga, ketidaksetiaan. Sang suami beberapa kali bepergian dengan wanita lain bahkan menjalin hubungan dengan wanita tersebut. Menurut informan, hal yang paling menyakitkan adalah sang suami melakukan hubungan intim dengan wanita lain tersebut yang adalah rekan di kantornya padahal statusnya masih resmi menikah dengan informan atau belum resmi bercerai.

Menurut informan istri yang kesembilan ada 3 hal yang seringkali menjadi pemicu pertengkaran. Pertama, kebiasaan buruk. Informan kesembilan ini mengatakan bahwa mantan suaminya memiliki kebiasaan buruk yaitu jarang pulang kerumah. la tidak mengetahui 
dengan jelas apa yang suaminya lakukan diluar rumah. Hal ini sering memicu pertengkaran diantara mereka. Kedua, ekonomi. Sang mantan suami tidak memiliki pekerjaan tetap sehingga penghasilanpun tidak menentu. Untuk mencukupi kebutuhan sehari - hari informan dan anaknya ditopang oleh orangtua informan ditambah dengan usaha rumahan yang dimiliki oleh informan. la pun menambahkan bahwa mantan suaminya terlihat tidak memiliki tanggung jawab sama sekali untuk membiayai dirinya dan anak tunggal mereka. Ketiga, ketidaksetiaan. Sang mantan suami adalah pribadi yang tidak setia. Informan mengatakan bahwa pada saat mereka masih terikat dalam pernikahan sah, sang mantan suami banyak membuka pembicaraan dengan wanita lain. Informan mendapati hal tersebut melalui media sosial sang mantan suami.

Menurut informan istri yang kesepuluh ada 3 hal yang seringkali menjadi pemicu pertengkaran. Pertama, kebiasaan buruk. Sang mantan suami menurut informan adalah pribadi yang kurang bertanggungjawab. Saat tidak memiliki pekerjaan lagi, sang mantan suami malah menyuruh informan untuk bekerja mencari nafkah, padahal sang mantan suami dalam keadaan sehat dan tidak dalam kondisi sakit apapun. Informan harus bekerja untuk menghidupi anak tunggal mereka yang masih kecil. Karena sikap tersebut, informan memutuskan untuk bercerai. Kedua, Komitmen. Informan menganggap bahwa sang mantan suaminya dulu tidak memiliki komitmen yang baik untuk membangun rumah tangga. Ketiga, ekonomi. Bagi informan, ekonomi adalah hal yang paling sering menjadi pemicu pertengkaran lantaran sang suami cenderung tidak bersungguh - sungguh mencari nafkah bagi keluarga kecil mereka. Informan juga harus bekerja untuk mencukupi kebutuhan keluarga.

Tabel 1.2 Persentase Faktor - Faktor Pertengkaran Rumah Tangga

\begin{tabular}{|c|c|c|}
\hline No & Faktor Pertengkaran dari Sudut Pandang Istri & Persentase \\
\hline 1 & Ketidaksetiaan & $42 \%$ \\
\hline 2 & Ekonomi & $33 \%$ \\
\hline 3 & Mertua/Keluarga lainnya & $33 \%$ \\
\hline 4 & Pekerjaan Rumah Tangga & $25 \%$ \\
\hline 5 & Kebiasaan Buruk & $25 \%$ \\
\hline 6 & Komitmen & $25 \%$ \\
\hline 7 & Seks & $17 \%$ \\
\hline
\end{tabular}




\begin{tabular}{|c|c|c|}
\hline 8 & Ponsel/Sosial Media & $17 \%$ \\
\hline 9 & Pengasuhan Anak & $17 \%$ \\
\hline 10 & Pekerjaan Prioritas Utama & $8 \%$ \\
\hline 11 & Kecanduan & $8 \%$ \\
\hline 12 & Anak & $0 \%$ \\
\hline
\end{tabular}

\section{Sumber: Olahan Peneliti}

Dari tabel di atas, telihat bahwa faktor terbanyak pertama yang sering menyebabkan pertengkaran dari sudut pandang istri adalah ketidaksetiaan sebanyak $42 \%$. Kemudian faktor terbanyak kedua yaitu ekonomi dan mertua/keluarga lainnya sebanyak $33 \%$, dan faktor terbanyak ketiga yaitu pekerjaan rumah tangga, kebiasaan buruk, dan komitmen sebanyak $25 \%$. Perincian alasan yang dikemukakan oleh masing - masing informan telah dicantumkan oleh peneliti pada bagian hasil wawancara. Berikut ini pemetaan hasil wawancara dari sudut pandang suami:

Tabel 1.3 Faktor - Faktor Umum Pertengkaran dari Sudut Pandang Suami

\begin{tabular}{|l|l|l|l|l|l|l|l|l|l|l|l|}
\hline No & Faktor-Faktor Umum Pertengkaran (Suami) & 1 & 2 & 3 & 4 & 5 & 6 & 7 & 8 & 9 & 10 \\
\hline 1 & Ponsel/Sosial Media & & & 1 & 1 & & & 2 & & 1 & \\
\hline 2 & Pekerjaan Rumah Tangga & & & & 2 & 1 & 1 & & & 2 & 1 \\
\hline 3 & Pengasuhan Anak & & & & & 3 & & & & & 3 \\
\hline 4 & Seks & 2 & 2 & & & & & & & & \\
\hline 5 & Komitmen & & & & & & & 3 & & & \\
\hline 6 & Ketidaksetiaan & 3 & 3 & & & & & & 3 & & \\
\hline 7 & Mertua/ Keluarga lainna & & & 3 & & 2 & & & & & \\
\hline 8 & Pekerjaan Prioritas Utama & & & 2 & & & 3 & & 1 & 3 & \\
\hline 9 & Ekonomi & 1 & 1 & & 3 & & 2 & & & & 2 \\
\hline 10 & Kebiasaan Buruk & & & & & & & & 2 & & \\
\hline 11 & Anak & & & & & & & \\
\hline
\end{tabular}

Menurut informan suami yang pertama, ada 3 hal yang sering menjadi pemicu pertengkaran dengan pasangannya. Pertama, kebiasaan buruk. Informan mengatakan bahwa istrinya sering menegurnya dengan nada yang tinggi dan tanpa memperhatikan situasi disekitar apakah ada 
orang yang mendengarkan atau tidak. la mengatakan bahwa hal tersebut sudah seringkali berulang bahkan sejak awal menikah hingga saat ini. Informan sering mengingatkan istrinya tentang hal tersebut, namun menurut informan istrinya memang memiliki karakter yang temperamen. Kedua, komitmen. Informan mengatakan bahwa istrinya sering mengambil keputusan secara sepihak tanpa melibatkan atau meminta saran dan pendapat informan, sehingga hal ini seringkali menjadi pemicu pertengkaran karena informan sebagai suami merasa kurang dianggap keberadaannya. Ketiga, mertua/keluarga lain. Informan mengatakan bahwa mertua ataupun keluarga lain kadang ikut campur dalam urusan rumah tangga informan, sehingga terkadang mempengaruhi sang istri.

Informan kedua menjelaskan ada 3 hal yang sering menjadi pemicu pertengkaran dalam rumahtangganya. Pertama, kebiasaan buruk. Informan mengatakan bahwa mantan istrinya adalah tipikal orang yang mudah marah dan curiga tanpa mencari tahu dulu kebenarannya seperti apa. la mengatakan sudah seringkali memberitahu kebiasaan buruk sang istri dan mengalah dengan situasi yang terjadi, namun tetap saja terulang kembali. Kedua, komitmen. Informan mengatakan bahwa mantan istrinya kurang memiliki komitmen untuk hidup berumahtangga dengan informan, mengapa? karena informan adalah seorang pelaut sehingga jarang menghabiskan waktu dengan mantan istrinya tersebut. Hal ini yang kemudian menimbulkan datangnya masukan atau hasutan dari keluarga sang mantan istri untuk menceraikan informan. Namun, informan mengatakan bahwa sampai saat ini ia masih memberikan kewajiban nafkahnya untuk anak tunggal mereka. Ketiga, mertua atau pasangan lain. Informan mengatakan bahwa karena ia jauh dari sang mantan istri menjadi seorang pelaut, sehingga mantan istrinya lebih sering mendengarkan masukan dari mertua dan keluarganya yang lain, sehingga seringkali menyebabkan timbulnya pertengkaran diantara informan dan sang mantan istri.

Menurut informan suami yang ketiga, menyebutkan ada tiga yang sering menjadi pertengkarannya dengan pasangan. Pertama, ponsel atau media sosial. Informan ketiga ini mengatakan bahwa istrinya terlalu sering bermain ponsel/sosial media sehingga waktu bersama keluarga berkurang. Kedua, ekonomi. Informan mengatakan ekonomi menjadi salah satu penyebab pertengkaran karena kondisi yang kurang stabil, padahal pengeluaran rumah tangga yang cukup banyak. Istri informan adalah seorang ibu rumah tangga tanpa bisnis/penghasilan sampingan. Ketiga, pekerjaan prioritas utama. Informan mengatakan 
bahwa saat ini prioritasnya adalah pekerjaan untuk menafkahi keluarganya, sehingga ia jarang menghabiskan waktu bersama keluarga karena harus bekerja diluar kota. Kurangnya komunikasi juga dapat menyebabkan mudahnya pasangan suami - istri tersulut emosi.

Menurut informan suami yang keempat, menyebutkan ada 3 hal yang sering menjadi pertengkarannya dengan pasangan. Pertama, ponsel atau sosial media. Menurut informan, sang istri lebih banyak menghabiskan waktu dengan bermain ponsel/media sosial. la mengatakan bahwa saat makan, istrinya juga membawa ponsel sambil mengecek semua grup whatsapp baik itu grup kantor, keluarga, ataupun mengecek sosial media. Informan sering merasa jengkel dengan perilaku istrinya tersebut sehingga sering menimbulkan pertengkaran. Kedua, pekerjaan rumah tangga. Informan mengatakan bahwa istrinya kurang inisiatif untuk mengurus rumah, misalnya menyapu. Untuk urusan menyapu rumah ataupun kebersihan lainnya didalam rumah lebih banyak diurus oleh informan sebagai suami, karena jika ia mengingatkan mengenai kebersihan pada istrinya, sang istri cenderung tidak terima dengan hal tersebut. Ketiga, kebiasaan buruk. Informan mengatakan bahwa istrinya adalah seorang perokok dan sudah berulangkali diingatkan oleh informan untuk berhenti dari kebiasaannya tersebut. la mengatakan istrinya susah berhenti merokok kemungkinan karena sudah mengalami ketergantungan.

Menurut informan yang kelima, menyebutkan ada tiga hal yang sering menjadi pertengkarannya dengan pasangan. Pertama, pekerjaan rumah tangga. Informan mengatakan bahwa ia dan sang istri sama - sama bekerja, sehingga seingkali pekerjaan pekerjaan rumah tangga tidak di handle dengan bijak dan baik. Masing - masing merasa sudah bekerja diluar rumah sehingga tidak fokus lagi untuk saling membantu dalam mengurus pekerjan rumah tangga. Hal ini kemudian yang menimbulkan pertengkaran diantara informan dan sang istri. Kedua, pekerjaan prioritas utama. Informan dan sang istri sama - sama bekerja sehingga, intensitas waktu untuk keluarga menjadi berkurang. Kurangnya diskusi diantara mereka inilah yang kemudian menurut informan sering menimbulkan kesalahpahaman. Ketiga, pengasuhan anak. Informan mengatakan bahwa ia dan sang istri menerapkan pola asuh yang keliru terhadap anak - anak mereka, dengan cara memanjakan dan melindungi secara berlebihan sehingga anak - anak menjadi sulit diatur. Hal ini kemudian yang kerap menjadi pemicu pertengkaran diantara informan dan sang istri karena saling menyalahkan. 
Menurut informan suami yang keenam, menyebutkan ada tiga hal yang sering menjadi pertengkarannya dengan pasangan. Pertama: pekerjaan rumah tangga. Informan dan sang istri sama - sama bekerja, sehingga membuat keduanya seringkali mengabaikan pekerjaan pekerjaan rumah tangga. Hampir mirip dengan kasus pada informan kelima, yang mana keduanya sama - sama bekerja, sehingga masing - masing merasa sudah cukup banyak mencurahkan tenaga dan pikiran untuk pekerjaan diluar rumah, yang akhirnya menyebabkan pekerjaan rumah tangga kurang mendapat perhatian. Kedua, kebiasaan buruk. Informan mengatakan bahwa sang istri memiliki kebiasaan buruk yang kurang bias ia terima, seperti meletakkan handuk basah diatas tempat tidur begitu saja sehabis mandi. Ini kerap menjadi pemicu pertengkaran dengan sang istri, karena informan adalah tipe orang yang rapi dan tidak suka melihat barang - barang diletakkan tidak pada tempatnya. Namun, informan menambahkan bahwa jika sang istri berada dalam kondisi mood yang sedang bagus maka ia kadangkala tanpa disuruh berulangkalipun langsung meletakkan handuk basah pada tempatnya sehabis mandi. Ketiga, ekonomi. Meskipun sang istri juga bekerja, namun informan tidak begitu menyukai sifat sang istri yang lumayan boros. Menurut informan ia lebih senang memperbaiki barang rusak dibandingkan harus membeli barang baru, namun apabila barang tersebut sudah rusak parah dan tidak bias diperbaiki lagi baru kemudian membeli barang baru menjadi jalan terakhir. Berbeda dengan sang istri yang lebih suka membeli barang baru sekalipun barang yang rusak sebelumnya masih bias diperbaiki.

Menurut informan suami yang ketujuh, menyebutkan ada 3 hal yang sering menjadi pertengkarannya dengan pasangan. Pertama, Seks. Informan merasa sebagai sang suami bahwa kebutuhannya akan seks diabaikan oleh istrinya. la mengatakan tidak mengetahui alasan yang pasti alasan mengapa istrinya tersebut cenderung menghindar setiap kali diajak untuk melakukan hubungan suami istri. Padahal sebagai suami dan kepala keluarga, ia sudah memenuhi kewajibannya dalam member nafkah pada keluarga. Kedua, Ponsel/Media Sosial. Informan mengatakan bahwa istrinya lebih sering mempergunakan waktunya untuk melihat lihat media social daripada menghabiskan waktu untuk quality time dengannya. la kerap menegur pola istrinya tersebut namun diabaikan. Sebagai tambahan informasi bahwa informan bekerja diluar kota atau tidak satu kota tinggal dengan istrinya, sehingga ia hanya bertemu istrinya jika mendapatkan libur atau cuti proyek. Ketiga, Ketidaksetiaan. Informan juga menyebutkan bahwa istrinya memang berlaku tidak setia yang dibuktikan dengan beberapa 
informasi yang masuk kepada informan. Namun, ia memilih untuk mempertahankan rumah tangganya mengingat anak - anaknya yang sudah beranjak dewasa.

Menurut informan suami yang kedelapan, menyebutkan ada tiga hal yang sering menjadi pertengkarannya dengan pasangan. Pertama, ekonomi. Informan mengatakan bahwa, istrinya adalah seorang ibu rumah tangga dengan tanpa pemasukan atau penghasilan sampingan, sehingga segala kebutuhan menjadi tanggungjawabnya sebagai suami dan kepala keluarga. Yang membuat informan kadang kesal dengan istrinya adalah gaya hidup istrinya yang bias dikatakan cukup boros, padahal cicilan rumah belum selesai. Hal ini menjadi salah satu pemicu keributan diantara mereka karena kemampuan istri dalam mengatur keuangan yang kurang baik. Kedua, anak. Informan dan sang istri belum dikaruniai buah hati, selama kurang lebih 6 tahun berumahtangga. Berbagai upaya telah dilakukan baik ia dan sang istri. Tidak dipungkiri bahwa hal ini juga menjadi salah satu pemicu pertengkaran diantara mereka. Informan menambahkan bahwa ialah yang sebenarnya tidak bias memiliki anak namun hanya bisa berusaha dan berdoa. Ketiga, mertua/Keluarga Lain. Mertua dan keluarga lain bahkan keluarga informan sendiripun juga kadang kala ikut campur dalam urusan rumah tangga informan dan sang istri.

Menurut informan suami yang kesembilan, menyebutkan ada 3 hal yang sering menjadi pertengkarannya dengan pasangan. Pertama, ponsel atau media sosial. Informan mengatakan kesal dengan istrinya jika sudah bermain ponsel, sang istri kadang lupa waktu dengan keluarga. Sebagai tambahan informan dan sang istri sama - sama bekerja. Kedua, Pekerjaan Rumah Tangga. Menurut informan, sang istri kadang lalai dalam menjalankan tugasnya sebagai seorang ibu rumah tangga, meskipun sebagai ibu bekerja juga. Menurutnya pekerjaan seharusnya bisa diseimbangkan antara pekerjaan kantor dan rumah. Informan menambahkan bahwa ia yang kerap kali mengasuh anak atau mengurus pekerjaan rumah tangga.Ketiga, ekonomi. Karena banyaknya kebutuhan keluarga, sehingga ia dan sang istri harus benar - benar mempertimbangkan pengeluaran, apalagi ditambah saat ini ada cicilan yang rutin untuk dibayarkan setiap bulan. Namun, ia melihat sang istri cukup boros mempergunakan uangnya. Karena sang istri juga bekerja sehingga kadangkala uang tersebut tidak digunakan untuk hal - hal yang benar - benar prioritas. 
Menurut informan yang kesembilan, menyebutkan ada 3 hal yang sering menjadi pemicu pertengkarannya dengan pasangan. Pertama, pekerjaan rumah tangga. Informan mengatakan bahwa sang istri kurang bijak dalam me-manage waktu untuk menyelesaikan pekerjaan - pekerjaan rumah tangga mana yang seharusnya diselesaikan terlebih dahulu. Kedua, Kebiasaan Buruk. Informan mengatakan bahwa, ia tidak begitu suka dengan kebiasaan istrinya yang dandan terlalu lama saat akan keluar rumah. la sebagai suami tidak bisa menunggu terlalu lama apalagi jika acara tersebut penting. Hal ini menurut informan bisa menjadi salah satu pemicu keributan diantara mereka. Ketiga, Pengasuhan Anak. Pola pengasuhan yang diterapkan oleh informan dan sang istri terhadap anak - anaknya berbeda. Perumpamaan informan seperti ada yang bertindak sebagai polisi yang baik ada yang bertindak sebagai polisi yang jahat.

Tabel 1.4 Persentase Faktor - Faktor Pertengkaran Rumah Tangga

\begin{tabular}{|c|c|c|}
\hline No & Faktor Pertengkaran Dari Sudut Pandang Suami & Persentase \\
\hline 1 & Pekerjaan Rumah Tangga & $42 \%$ \\
\hline 2 & Kebiasaan Buruk & $42 \%$ \\
\hline 3 & Ponsel/Sosial Media & $33 \%$ \\
\hline 4 & Ekonomi & $33 \%$ \\
\hline 5 & Mertua/Keluarga lainnya & $25 \%$ \\
\hline 6 & Komitmen & $17 \%$ \\
\hline 7 & Pekerjaan Prioritas Utama & $17 \%$ \\
\hline 8 & Pengasuhan Anak & $17 \%$ \\
\hline 9 & Seks & $8 \%$ \\
\hline 10 & Anak & $8 \%$ \\
\hline 11 & Ketidaksetiaan & $8 \%$ \\
\hline
\end{tabular}

Dari tabel di atas, terlihat bahwa faktor terbanyak pertama yang sering menyebabkan pertengkaran dari sudut pandang suami adalah pekerjaan rumah tangga dan kebiasaan buruk sebanyak $42 \%$. Kemudian faktor terbanyak kedua yaitu ponsel/sosial media dan ekonomi sebanyak $33 \%$, dan posisi terbanyak ketiga yang sering menyebabkan pertengkaran antara informan dan pasangan yaitu mertua/keluarga lain sebanyak $25 \%$. 
Pertengkaran dalam rumah tangga yang dialami oleh para informan tentu saja masing masingnya berbeda antara satu dengan yang lain. Masing - masing informan tersebut telah memberikan penjelasan mengenai faktor - faktor yang membuat mereka mengalami konflik dengan pasangannya ataupun mantan pasangannya, karena beberapa diantara informan tersebut sudah resmi berpisah dengan pasangannya.

Untuk membahas hasil penelitian di atas, peneliti menggunakan dua jenis teori. Pertama, Teori Pelanggaran Harapan (Expectancy Violations Theory). Teori Pelanggaran Harapan adalah sebuah teori yang menjelaskan bahwa setiap orang memiliki harapan mengenai perilaku orang lain berdasarkan norma - norma sosial, pengalaman sebelumnya yang terjadi dengan orang tersebut, dan situasi dimana perilaku itu terjadi.

Harapan - harapan terhadap perilaku orang lain tersebut mencakup perilaku non verbalnya antara lain kontak mata (eye contact), jarak antara kita dengan orang tersebut, serta sudut tubuh (body angle). Menurut Burgoon, ketika seseorang memenuhi harapan Anda, maka Anda cenderung tidak memperhatikan perilakunya, sehingga tidak memberikan penilaian, namun jika terjadi pelanggaran dan Anda merasa terganggu maka disitulah baru Anda membuat penilaian, Morissan (2013: 216).

Kedua, Teori Komunikasi Behaviorisme. Menurut teori ini, semua perilaku termasuk tindak balas atau respon muncul akibat adanya rangsangan atau stimulus, dimana jika rangsangan telah diamati dan diketahui maka tindakan untuk memberikan balasan atau respon pun dapat diprediksi.

Tokoh aliran teori Behaviorisme ini adalah John B Watson, dimana teori ini lahir sebagai reaksi terhadap introspeksionisme dan juga psikoanalisis. Teori ini tidak menyinggung mengenai apakah individu yang bersangkutan adalah baik atau buruk, rasional atau emosional, namun teori ini hanya ingin mengetahui bagaimana perilaku seseorang dikendalikan oleh lingkungan, Oktarina dan Abdullah (2017: 88).

Berdasarkan kedua teori yang dipaparkan oleh peneliti di atas, sangat erat keterkaitannya dengan hasil wawancara para informan. Kedua teori tersebut akan digunakan oleh peneliti untuk membedah hasil penelitian ini. 
Teori pertama yang digunakan adalah Teori Pelanggaran Harapan atau Expectancy Violations Theory. Mengapa terjadi pertengkaran antara suami dan istri? menurut teori ini hal tersebut terjadi karena kedua belah pihak ternyata kurang mampu "memenuhi" harapan masing masing pasangannya dalam berumahtangga. Memang, tidak ada satupun interaksi rumah tangga di dunia ini yang benar - benar sempurna, tenang, damai, dan tanpa pertengkaran, karena setiap manusia memiliki kekurangan dan kelebihan masing - masing. Oleh sebab itu, konflik dalam rumah tangga adalah hal yang lumrah terjadi.

Teori Pelanggaran Harapan ini, sangat pas untuk dijadikan sebagai landasan teori untuk melihat bagaimana konflik terjadi di antara suami dan istri. Misalnya saja, menurut pihak istri (persentase pemilih 42\%) menganggap bahwa suami mereka adalah pribadi yang tidak setia. Hal tersebut bisa benar adanya bisa juga tidak. Jika ditinjau dari sudut pandang pihak istri yang memilih poin ketidaksetiaan tersebut, hal itu tentu saja benar berdasarkan pengalaman mereka dengan sang suami. Pihak istri menganggap bahwa suami mereka memiliki orang lain diluarsana, baik yang tidak diketahui maupun yang sudah diketahui oleh pihak istri. Hal inilah yang kemudian membuat pihak suami sebagai pelanggar harapan dari istri mereka. Istri berharap bahwa sang suami bias setia terhadap keluarga, namun ternyata hal tersebut tidak sesuai dengan harapan. Dari sinilah timbul konflik dan pertengkaran karena salah satu pihak menganggap bahwa harapan yang ia miliki terhadap pasangannya dilanggar.

Lain halnya dengan pihak istri yang banyak memilih poin ketidaksetiaan (42\%), pihak suami lebih banyak memilih poin pekerjaan rumah tangga $(42 \%)$ sebagai faktor yang memicu pertengkaran. Misalnya saja, pihak istri lebih banyak menghabiskan waktu untuk mengerjakan hal lain dibandingkan dengan tugas utamanya dalam mengurus rumah tangga. Hal ini bias saja benar adanya namun bisa juga tidak. Dari sudut pandang suamiapa yang dilakukan oleh pihak istri adalah hal yang keliru, sehingga muncullah konflik diantara mereka. Pihak suami menganggap istri mereka lalai dalam hal tersebut.

Pertengkaran yang timbul kemudian memunculkan jawaban bahwa ada harapan dari masing - masing pihak yang dilanggar oleh pasangannya. Pihak suami merasa benar, dan menganggap bahwa istrilah yang keliru sehingga timbul konflik. Pihak istri pun juga menganggap bahwa pihak suamilah yang keliru sehingga mereka terjebak dalam pertengkaran. 
Teori kedua yang digunakan oleh peneliti adalah Teori Behaviorisme, yang secara garis besar menjelaskan mengenai bagaimana perilaku seseorang dikendalikan oleh lingkungan. Teori ini sangat berkaitan pula dengan pertengkaran ataupun konflik yang terjadi antara suami dan istri dalam rumah tangga. Bagaimana sikap dan perilaku suami kemudian mendapatkan respon dari istri, dan begitupun sebaliknya, bagaimana sikap dan perilaku istri direspon oleh suami.

Sebagai contoh, istri menganggap bahwa mertua/keluarga lain (33\%) turut campur dalam urusan rumah tangga mereka. Istri kemudian melihat bagaimana sikap dan perilaku suami dalam merespon situasi ini, karena hal tersebut nantinya akan mendapatkan respon balik dari pihak istri. Jika istri merasa suami bijaksana, maka pertengkaran diantara mereka dapat diminimalisir, namun jika pihak istri merasa bahwa suami tidak bijaksana maka hal tersebut yang dapat memicu terjadinya pertengkaran diantara mereka.

Hal lain misalnya, suami menganggap bahwa istri mereka terlalu boros yang berkaitan dengan ekonomi $(33 \%)$ sehingga abai terhadap kebutuhan - kebutuhan pokok yang seharusnya mendapat prioritas utama. Sikap dan perilaku istri ini yang kemudian mendapatkan respon dari pihak suami. Jika mereka bias menemukan jalan tengah terhadap situasi tersebut maka pertengkaran dapat diminimalisir, namun jika tidak maka konflik akan terjadi

\section{KESIMPULAN}

Berdasarkan hasil penelitian di atas dapat disimpulkan bahwa pertengkaran yang terjadi antara suami dan istri adalah hal lumrah yang dialami oleh siapa saja yang berumahtangga. Hal tersebut terjadi karena adanya perbedaan harapan yang dimiliki oleh masing - masing pihak terhadap pasangannya serta respon yang timbul dari salah satu pihak akibat sikap dan perilaku dari pasangannya.

Jalan tengah yang bisa dilakukan untuk meminimalisir pertengkaran antara suami dan istri adalah berdiskusi atau berkomunikasi dengan pasangan, membicarakan hal - hal yang menjadi keinginan dan harapan dari masing - masing pihak, serta belajar untuk saling menerima kekurangan dan kelebihan masing - masing, karena tidak ada pasangan yang sempurna. 


\section{REFERENSI}

Aloysius, H. (2002). Surat UntukSuami Istri Katolik. Yogyakarta: Kanisius.

Dinda, A. (2018). Surga Perkawinan : Referensi Perkawinan Berkah dan Pilar-Pilar Menggapai Rumah Tangga Menuju Surga Perkawinan. Pangandaran: Arda Publishing.

Gunawan. (2019). Bagaimana Mengubah Suami/lstri Anda Menjadi Lebih Romantis. Sleman: Deepublish.

Istijanto. (2009). Aplikasi Praktis Riset Pemasaran. Jakarta: Gramedia Pustaka Utama.

Luthfiyah, M. F. (2018). Metodologi penelitian: Penelitian kualitatif, tindakan kelas \& studi kasus. Sukabumi: CV Jejak.

Manzilati, A. (2017). Metodologi Penelitian Kualitatif: Paradigma, Metode, Dan Aplikasi. Malang: Universitas Brawijaya Press.

M I., \& Fawzea, K. (2020). Psikologi Pasangan: Manajemen Konflik Rumah Tangga. Depok: Gema Insani.

Morissan. (2015). Teori Komunikasi Individu Hingga masa. Jakarta: Kencana.

Morissan. (2019). Riset Kualitatif. Jakarta: Kencana.

Puteri, Amelia (2019). Lima Pertengakaran Rumah Tangga Normal Yang Bahkan Terjadi Pada Pasangan Bahagia. https://parenting.orami.co.id/magazine/5-pertengkaran-rumahtangga-normal-yang-bahkan-terjadi-pada-pasangan-bahagia/

Semiawan, C. R. (2010). Metode Penelitian Kualitatif. Jakarta: Grasindo.

Syuhud, A. F. (2014). Merajut Rumah Tangga Bahagia. Malang: Pustaka Alkhoirot.

Tashandra, Nabila. (2020). Hal Sepele Pemicu Pertengkaran Dengan Pasangan Yang Perlu Dihindari. https://lifestyle.kompas.com/read/2020/01/16/111829220/hal-sepelepemicu-pertengkaran-dengan-pasangan-yang-perlu-dihindari?page=all

Utarini, A. (2020). Tak Kenal Maka Tak Sayang: Penelitian Kualitatif dalam Pelayanan Kesehatan. Yogyakarta: UGM Press.

Yetty Oktarina, Y. (2017). Komunikasi dalam Perspektif Teori Dan Praktik. Sleman: Deepublish. 